\title{
Correction to: Teachers' use of class talk interaction as a predictor of learning outcomes in chemistry
}

\section{Newton Irungu Mwangi ${ }^{1}$ - Grace Mutitu Nyagah ${ }^{1} \cdot$ Mercy Muthoni Mugambi $^{1}$}

Published online: 26 January 2021

(C) Springer Nature Switzerland AG 2021

\section{Correction to: SN Soc Sci (2021) 1:3 https://doi.org/10.1007/s43545-020-00009-1}

The article Teachers' use of class talk interaction as a predictor of learning outcomes in chemistry, written by Newton Irungu Mwangi, Grace Mutitu Nyagah \& Mercy Muthoni Mugambi, was originally published online on the publisher's internet portal on 9 November 2020 with Open Access under a Creative Commons Attribution (CC BY) license 4.0. With the author's/authors' decision to cancel Open Access the copyright of the article changed on 1 January 2021 to (C) Springer Nature Switzerland AG 2021 with all rights reserved.

The original article can be found online at https://doi.org/10.1007/s43545-020-00009-1.

Newton Irungu Mwangi

mwanginewton61@yahoo.com

1 Department of Educational Administration and Planning, College of Education and External Studies, University of Nairobi, P.O Box 30197, Nairobi 00100, G.P.O, Kenya 